\title{
Effect of carbon source on acclimatization of nitrifying bacteria to achieve high-rate partial nitrification of wastewater with high ammonium concentration
}

\author{
Seyyed Alireza Mousavi • Shaliza Ibrahim • \\ Mohamed Kheireddine Aroua
}

Received: 18 January 2014 / Accepted: 22 July 2014/Published online: 24 August 2014

(C) The Author(s) 2014. This article is published with open access at Springerlink.com

\begin{abstract}
Experiments in two laboratory-scale sequential batch reactors were carried out to investigate the effect of heterotrophic bacteria on nitrifying bacteria using external carbon sources. Partial nitrification of ammonium-rich wastewater during short-term acclimatization enriched the activity of ammonia-oxidizing bacteria in both reactors. Heterotrophic bacteria exhibited a minor effect on nitrifying bacteria, and complete removal of ammonium occurred at a rate of $41 \mathrm{mg} \mathrm{L}^{-1} \mathrm{~h}^{-1}$ in both reactors. The main strategy of this research was to carry out partial nitrification using high-activity ammonia-oxidizing bacteria with a high concentration of free ammonia $\left(70 \mathrm{mg} \mathrm{L}^{-1}\right)$. The $\mathrm{NO}_{2}^{-}$/ $\left(\mathrm{NO}_{3}{ }^{-}+\mathrm{NO}_{2}{ }^{-}\right)$ratio was greater than 0.9 in both reactors most of the time.
\end{abstract}

Keywords Nitrification - Nitrifying bacteria .

Ammonium-rich wastewater $\cdot$ Partial nitrification

\section{Introduction}

The uncontrolled discharge of wastewater containing ammonia in water bodies through nitrogen-rich wastewaters

S. A. Mousavi $(\bowtie)$

Department of Environmental Health, Kermanshah University of Medical Sciences, Kermanshah, Iran

e-mail: seyyedarm@yahoo.com

S. A. Mousavi - S. Ibrahim

Department of Civil Engineering, Faculty of Engineering,

University of Malaya, 50603 Kuala Lumpur, Malaysia

M. K. Aroua

Department of Chemical Engineering, Faculty of Engineering,

University of Malaya, 50603 Kuala Lumpur, Malaysia has been considered as a worldwide human health threat and toxicity to aquacultures (Chen et al. 2006; Mousavi et al. 2012). Among different sources of nitrogen components, anaerobic sludge digesters effluent (sludge rejected water) generally contains $15-25 \%$ of the total nitrogen load in a flow and is recycled to the head of the sewage treatment works (Mata-Alvarez 2002; Dosta et al. 2007). In addition, the remaining COD in this effluent is weakly biodegradable. Different processes have been tested to find a suitable method for treating this kind of wastewater (Van Kempen et al. 2001).

In the past decades, both physicochemical and biological methods have been used for ammonium removal from wastewater to obtain discharge standards (KomorowskaKaufman et al. 2006). Some drawbacks of physicochemical technologies for ammonia removal have shifted research interest toward biological nitrogen removal (BNR) as a promising method for eliminating ammonia from wastewater (Dosta et al. 2007). Biological ammonia removal normally takes place in two steps, namely, nitrification and denitrification. Nitrification is also a two-step process, where ammonium is firstly oxidised to nitrite by ammonium-oxidising biomass (AOB). This process is called nitritation and its stoichiometry is:

$\mathrm{NH}_{4}^{+}+3 / 2 \mathrm{O}_{2} \rightarrow \mathrm{NO}_{2}^{-}+2 \mathrm{H}^{+}+\mathrm{H}_{2} \mathrm{O}$

Secondly, nitrite is oxidised to nitrate by nitrite-oxidising biomass (NOB). This process is called nitratation and its stoichiometry is:

$\mathrm{NO}_{2}^{-}+1 / 2 \mathrm{O}_{2} \rightarrow \mathrm{NO}_{3}^{-}$

The rate of the nitrification process depends on the activities of nitrifying bacteria and is affected by environmental and operational parameters (e.g., 
temperature, $\mathrm{pH}$ microorganism population, organic carbon and nitrogen concentration). Optimizing factors affecting the nitrogen removal process is thus necessary to build up nitrifying bacteria and increase the effectiveness of wastewater treatment investigations (KomorowskaKaufman et al. 2006). The heterotroph/autotroph population ratio depends on the organic carbon/nitrogen ratio $(\mathrm{C} / \mathrm{N})$ in wastewater. According to the results of previous studies, at high ratio of $\mathrm{C} / \mathrm{N}$, heterotrophic bacteria dominate the nitrifying bacteria, resulting in a decrease of ammonium removal (Okabe et al. 1996; Campos et al. 1999; Carrera et al. 2004; Wu et al. 2008). Rostron et al. (2001) investigated the effect of COD (glucose) addition on nitrification at $12 \mathrm{~h}$ of operational HRT. In this condition, heterotrophic bacteria grow rapidly and reduce influent COD by $90 \%$ within 10 days of adding $500 \mathrm{mg} \mathrm{L}^{-1}$ COD to the feed. Results indicated that all three reactors lost nitrate production because of limited oxygen for nitrifying bacteria, which can be attributed to the dominance of heterotrophs (Rostron et al. 2001).

Research has shown the complexity of AOB enrichment in a single reactor and considerably low rates of system efficiency. On the other hand, a solid retention time (as a controlling parameter) of less than 4 days has been reported to cause washout of nitrifying microorganisms, thus reducing the nitrification rate (Campos et al. 1999). In addition, ammonia oxidation in a single reactor is usually limited to $0.2 \mathrm{~kg} \mathrm{~N}-\mathrm{NH}_{4}{ }^{+} \mathrm{m}^{-3}$ per day. Therefore, using two biological units, with the nitrification process taking place individually in the subsequent unit, to prevail over the above-described limitations was recommended (Campos et al. 1999; Wu et al. 2008). On the other hand, using a single reactor for nitrification increases the initial capital and maintenance cost, which encourage researchers to develop energy-saving nitrogen elimination systems and increase the nitrification rate by applying cost-effective methods, such as SHARON (Van Kempen et al. 2001) and Anammox (Volcke et al. 2006), for treatment of sludge rejected water (Chen et al. 2010).

This preliminary study evaluated the role of the $\mathrm{C} / \mathrm{N}$ ratio, among several factors affecting microbial growth, as an inhibitor in the nitrification process. In addition, the feasibility of partial nitrification (PN) as a cost-effective process was investigated during enrichment of nitrifying bacteria with a high concentration of ammonium. This work lays the groundwork for further research on bioelectrochemical nitrogen elimination.

\section{BNR via nitrite}

This section discusses the importance and mechanisms of PN to elucidate the process. PN occurs via AOB according to Eq. 1, but activated sludge is a mixed culture containing both AOB and NOB. As such, researchers have carried out BNR via nitrite by adjusting the environmental and operational parameters ( $\mathrm{pH}$, dissolved oxygen, temperature, and substrate concentrations) to limit the growth of NOB and enrich AOB, which cause nitrite accumulation (Dosta et al. 2007; Blackburne et al. 2008; Chen et al. 2010). Savings of $25 \%$ in aeration costs using low concentrations of dissolved oxygen only to enrich $\mathrm{AOB}$ and a reduction of $40 \%$ of the external carbon source needed during denitrification by limiting NOB in PN have been reported (Ruiz et al. 2003). Free ammonia (FA) and free nitrous acid are inhibition parameters that play key roles in PN. The values of both substrates depend on the total ammonia concentration, $\mathrm{pH}$, and temperature (Grunditz and Dalhammar 2001; Whang et al. 2009). Previous studies have shown the inhibitory effect of high concentrations of $\mathrm{FA}$ and $\mathrm{HNO}_{2}$ on AOB and NOB in PN (Chen et al. 2010). Blackburne et al. (2008) investigated the role of high-concentration FA in inhibiting Nitrobacter and Nitrospira activities and found that Nitrospira species are much more sensitive to low concentrations of FA than Nitrobacter species. In addition, NOB were found to be inhibited at concentrations higher than $0.1-1 \mathrm{mg} \quad \mathrm{NH}_{3} \mathrm{~L}^{-1}$ and/or $0.2-2.8 \mathrm{mg}$ $\mathrm{HNO}_{2} \mathrm{~L}^{-1}$, whereas AOB were inhibited by unionized ammonia concentrations higher than $10-150 \mathrm{mg} \mathrm{NH}_{3} \mathrm{~L}^{-1}$. These findings suggest that enrichment of nitrifying bacteria can enhances the nitrification rate. For example, Zheng et al. (2004) examined the high activity of AOB in a pure culture (6-8 $\mathrm{g} \mathrm{NH}_{4}^{-}-\mathrm{N} \mathrm{g}^{-1}$ VSS per day). Moreover, Chen, et al. (2010) investigated the enrichment of high nitrifier activity with the aim of enhancing the performance of the PN process and reported a specific ammonium oxidation rate (2.78 $\mathrm{g} \mathrm{NH}_{4}{ }^{+}-\mathrm{N} \mathrm{g}^{-1}$ VSS per day) higher than previously reported values $\left(0.6 \mathrm{~g} \mathrm{NH}_{4}{ }^{+}-\mathrm{N} \mathrm{g}^{-1}\right.$ VSS per day (Ciudad et al. 2007), $1.54 \mathrm{~g} \mathrm{NH}_{4}^{+}-\mathrm{N} \mathrm{g}^{-1}$ VSS per day (Kim et al. 2009), and $2.76 \mathrm{~g} \mathrm{NH}_{4}{ }^{+}-\mathrm{N} \mathrm{g}^{-1}$ VSS per day (Jianlong and Ning 2004)).

\section{Materials and methods}

Seed sludge and synthetic wastewater

A biomass with a mixed culture nitrifying bacteria was obtained from the activated sludge of an urban wastewater treatment plant (WWTP) in Pantai Dalam, Kuala Lumpur, Malaysia. The activated sludge was filtered to remove wastes and washed repeatedly to remove internal nitrogen components $\left(\mathrm{NH}_{4}{ }^{+}, \mathrm{NO}_{2}{ }^{-}\right.$, and $\left.\mathrm{NO}_{3}{ }^{-}\right)$. The sludge was then dewatered and kept in a growth medium in a cold room $\left(4{ }^{\circ} \mathrm{C}\right)$ for future use. Sludge with an initial mixedliquor suspended solid (MLSS) concentration of $2 \mathrm{~g} \mathrm{~L}^{-1}$ 
Table 1 Synthetic wastewater compositions

\begin{tabular}{|c|c|}
\hline Constituent & Concentration $\left(\mathrm{mg} \mathrm{L}^{-1}\right)$ \\
\hline $\mathrm{NH}_{4}-\mathrm{N}$ & 2,000 \\
\hline $\mathrm{NaHCO}_{3}$ & 6,000 \\
\hline $\mathrm{KH}_{2} \mathrm{PO}_{4}$ & 400 (as P) \\
\hline $\operatorname{MgSO} 4 \cdot(g / 1)$ & 120 \\
\hline Glucose & 0 and 1,000 \\
\hline $\mathrm{pH}$ & 8 \\
\hline \multicolumn{2}{|c|}{ Composition of trace element solution $(1 \mathrm{ml} /$ pre liter of reactor } \\
\hline EDTA & 10 \\
\hline $\mathrm{ZnSO}_{4} \cdot 7 \mathrm{H}_{2} \mathrm{O}$ & 2.2 \\
\hline $\mathrm{CoCL}_{2} \cdot 6 \mathrm{H}_{2} \mathrm{O}$ & 3.2 \\
\hline $\mathrm{MnCl}_{2} \cdot 4 \mathrm{H}_{2} \mathrm{O}$ & 10.2 \\
\hline $\mathrm{CuSO}_{4} \cdot 5 \mathrm{H}_{2} \mathrm{O}$ & 0.22 \\
\hline$\left(\mathrm{NH}_{4}\right)_{6} \mathrm{Mo}_{7} \mathrm{O}_{24} \cdot 4 \mathrm{H}_{2} \mathrm{O}$ & 2.2 \\
\hline $\mathrm{CaCl}_{2} \cdot 2 \mathrm{H}_{2} \mathrm{O}$ & 1.1 \\
\hline $\mathrm{FeSO}_{4} \cdot 7 \mathrm{H}_{2} \mathrm{O}$ & 10 \\
\hline $\mathrm{H}_{3} \mathrm{BO}_{3}$ & 0.3 \\
\hline $\mathrm{NiSO}_{4} \cdot 6 \mathrm{H}_{2} \mathrm{O}$ & 1 \\
\hline
\end{tabular}

was inoculated into two $5 \mathrm{~L}$ sequencing batch reactors to acclimatize with high-strength ammonium. A headspace of $1 \mathrm{~L}$ was provided to prevent any solid loss generally caused by foaming. The reactors were fed with synthetic wastewater according to Table 1 . The synthetic wastewater was stored in a cold room at temperature below $4{ }^{\circ} \mathrm{C}$. The feed temperature increased to $25{ }^{\circ} \mathrm{C}$ before input to the SBRs by a water bath. The SBRs were fed with synthetic wastewater containing different $\mathrm{C} / \mathrm{N}$ ratio with $1,000 \mathrm{mg} \mathrm{L}^{-1}$ of $\left(\mathrm{NH}_{4}\right)_{2} \mathrm{SO}_{4}$ as the source of nitrogen. The source of phosphorus was $200 \mathrm{mg} \mathrm{L}^{-1} \mathrm{KH}_{2} \mathrm{PO}_{4}$, and carbon was prepared using $3,000 \mathrm{mg} \mathrm{L}^{-1} \mathrm{NaHCO}_{3}$ to achieve a suitable ratio of $\mathrm{C} / \mathrm{N}$. Trace elements were adjusted by adding $1 \mathrm{~mL} / \mathrm{L}$ of stock solution according to Table 1 .

\section{Experimental setup}

The enrichment of high-activity AOB was conducted in a laboratory-scale sequencing batch reactor (SBR) with a working volume of $5 \mathrm{~L}$ (Fig. 1). Two reactors (R1, R2) were run in multiple cycles with sequencing stages of $23 \mathrm{~h}$ reaction, $50 \mathrm{~min}$ settling, $5 \mathrm{~min}$ decanting, and $5 \mathrm{~min}$ filling, with each cycle lasting no less than $24 \mathrm{~h}$. The reactors were provided with a thermostatic jacket, and temperature was maintained at $30 \pm 0.5^{\circ} \mathrm{C}$ using a thermostatic bath. The suspension medium was mechanically agitated throughout the reaction time. The stirring rate was controlled to be adequate (200 rpm) to create a uniform biomass suspension. Two air pumps (HAILEA, ACO-9820, China) supplied air that was fed from the bottom of the reactors, and dissolved oxygen was measured with an electrode (METTLER TOLEDO, $\mathrm{O}_{2}$-sensor, Switzerland) and maintained higher than $3 \mathrm{mg} \mathrm{L}^{-1}$ by adjusting the air flow rate manually. $\mathrm{pH}$ was measured with an electrode (METTLER TOLEDO, ph-sensor, Switzerland) and adjusted between 7.3 and 7.9 by automatic injection of acid $\left(\mathrm{H}_{2} \mathrm{SO}_{4} ; 1 \mathrm{~N}\right)$ or alkaline $(\mathrm{NaOH} 1 \mathrm{~N})$ solution, respectively. The decanting ratio of feed was 0.5 . At the end of each settling phase, $50 \%$ of the reactor contents was decanted and replaced with new feed. Furthermore, no sludge removal and MLSS of effluent returned to the reactors, with the centrifugation at 3,600 rpm for $10 \mathrm{~min}$ for all decanted samples.

Analytical methods

The samples were either analyzed immediately or stored at temperature below $4{ }^{\circ} \mathrm{C}$ until subjected to analysis. The determination of ammonium, nitrate, and nitrite concentrations was done using an Advanced Compact IC 861 (Metrohm ${ }^{\circledR}$ Ltd., Herisau, Switzerland) ion chromatograph (IC) and guard column. The eluents to determine cation and anion were prepared using ultrapure water $(18.2 \mu \mathrm{s})$ containing pyridin-2, 6-dicarbonsäure $(0.117 \mathrm{~g} / \mathrm{L})$, and $\mathrm{HNO}_{3}(0.11 \mathrm{~mL} / \mathrm{L})$ for cation, and $\mathrm{NaCO}_{3}(0.3392 \mathrm{~g} / \mathrm{L})$, $\mathrm{NaHCO}_{3}(0.084 \mathrm{mg} / \mathrm{L})$, and $\mathrm{H}_{2} \mathrm{SO}_{4}(0.1 \mathrm{~mol})$ for anion, respectively. Before analyses, the samples were centrifuged and filtered with a $0.2 \mu \mathrm{m}$ filter. The process temperature, $\mathrm{pH}, \mathrm{DO}$, and ORP were continually monitored by a digital controller. In addition, the MLSS and MLVSS were determined following standard methods (APHA et al. 2012). Experiments were repeated if an error higher than $5 \%$ occurred in the sample analysis. By adjusting $\mathrm{pH}$, temperature, and the remaining concentration of ammonium, FA and FNA concentrations were calculated according to Eqs. 3 and 4 (Chen et al. 2010). The operating conditions in this research are summarized in Table 2.

$$
\begin{aligned}
& \mathrm{FA}(\mathrm{mg} / \mathrm{L})=\frac{17}{14} \times \frac{\left[\mathrm{NH}_{4} \cdot \mathrm{N}\right] \times 10^{\mathrm{pH}}}{\exp [6344 /(273+T)]+10^{\mathrm{pH}}} \\
& \operatorname{FNA}(\mathrm{mg} / \mathrm{L})=\frac{46}{14} \times \frac{\left[\mathrm{NO}_{2}^{-} \cdot \mathrm{N}\right]}{\exp [-2300 /(273+T)] \times 10^{\mathrm{pH}}}
\end{aligned}
$$

\section{Results and discussion}

\section{Acclimatization performance of the HA-AOB}

The experiments were carried out by feeding the reactors in parallel at $30 \pm 0.5{ }^{\circ} \mathrm{C}$ with an initial $\mathrm{NH}_{4}{ }^{+}-\mathrm{N}$ concentration of $1,000 \mathrm{mg} \mathrm{L}^{-1}$, which is considered to be highly contaminated ammonium wastewater. The reaction time (RT) was maintained at $23 \mathrm{~h}$ for both reactors. Ammonium 
Fig. 1 Schematic diagram of the experimental apparatus (SBR)

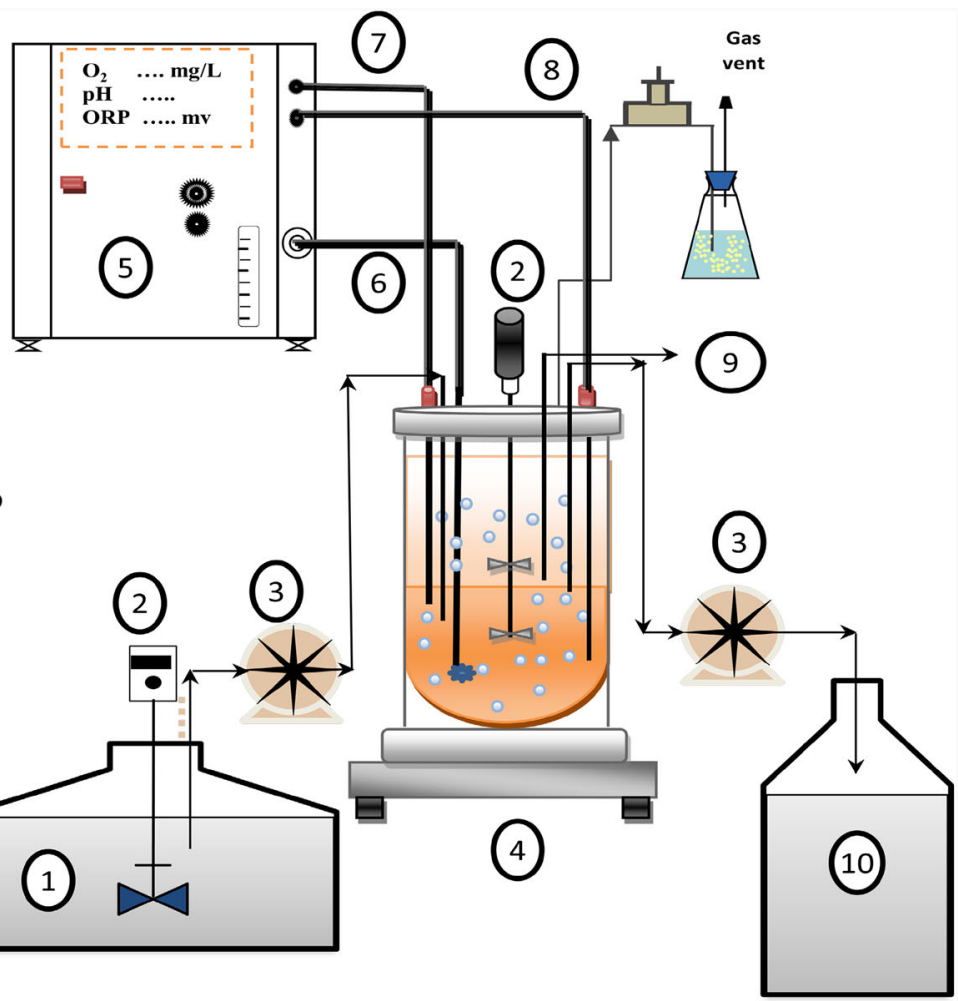

Table 2 Operational conditions of the SBRs

\begin{tabular}{|c|c|c|}
\hline parameters & $R 1$ & $R 2$ \\
\hline Temperature $\left({ }^{\circ} \mathrm{C}\right)$ & $30 \pm 0.5$ & $30 \pm 0.5$ \\
\hline $\mathrm{DO}\left(\mathrm{mg} \mathrm{L}^{-1}\right)$ & $>3$ & $>3$ \\
\hline HRT (h) & 48 & 48 \\
\hline Cycle (h) & 24 & 24 \\
\hline MLSS (mg L $\left.{ }^{-1}\right)$ & 2,000 & 2,000 \\
\hline $\operatorname{MLVSS}\left(\mathrm{mg} \mathrm{L}^{-1}\right)$ & 1,650 & 1,650 \\
\hline $\mathrm{pH}$ & $7.6 \pm 0.3$ & $7.6 \pm 0.3$ \\
\hline $\mathrm{NH}_{4}-\mathrm{N}\left(\mathrm{mg} \mathrm{L}^{-1}\right)$ & 2,000 & 2,000 \\
\hline $\mathrm{COD} / \mathrm{N}$ & 0 & 0.5 \\
\hline Volumetric exchange rate $(\%)$ & 50 & 50 \\
\hline
\end{tabular}

reduction and generation of nitrite and nitrate were observed soon after the run of reactors. The total cycle lengths for SBR due to high concentration of ammonia, slow growth of autotrophic bacteria, and limit of interference of loss of biomass during decanting time were maintained until complete nitrification of $1,000 \mathrm{mg} \mathrm{L}^{-1}$ $\mathrm{NH}_{4}{ }^{+}-\mathrm{N}$ within $24 \mathrm{~h}$.

The startup of reactors was subject to the growth and adaptation of HA-AOB and the inhibition of NOB with the presence and absence of heterotrophic bacteria. Synthetic wastewater containing glucose as a carbon source was added to R2 to investigate the effect of heterotrophic bacteria on the nitrification process. The addition had a marginal effect on the nitrification rate. $\mathrm{pH}$ and $\mathrm{DO}$ were automatically kept within the range of $7.6 \pm 0.3$ and $\geq 3 \mathrm{mg} \mathrm{L}^{-1}$ for both groups of bacteria (heterotrophic and autotrophic bacteria, respectively) (Gerardi 2002; Wu et al. 2008). An MLSS concentration of $2 \mathrm{~g} \mathrm{~L}^{-1}$ was maintained throughout the experiment with mixed liquor purged from the reactors, and the centrifuged biomass of effluent was returned to the reactors. Therefore, stable operation was assumed throughout the experiment.

\section{Effect of $\mathrm{C} / \mathrm{N}$}

Figure 2 shows that a complete removal of ammonium in $R 1$ (C/N ratio 0) was achieved at a shorter cycle $(144 \mathrm{~h})$ than $R 2$ (C/N ratio 0.5$)$, in which complete ammonium removal occurred after $156 \mathrm{~h}$. However, at the beginning of the process, $R 2$ showed higher efficiency in reducing ammonium, which may be due to quick activation of the process by heterotrophic bacteria. Figure 2 demonstrates that in $R 1$ after 11.5 days during four cycles, acclimatization of nitrifying bacteria at $\mathrm{C} / \mathrm{N}=0$ was observed. The ammonium reduction was less in $R 2$ than $R 1$, which can be due to glucose adding. The presence of organic carbon in $R 2$ can support the growth of heterotrophs and inhibit the activity of nitrifying bacteria (Van Benthum et al. 1997). Researchers confirmed the improvement of nitrification at low temperatures in the presence of heterotrophic bacteria, because they act as a protective layer for the nitrifying 


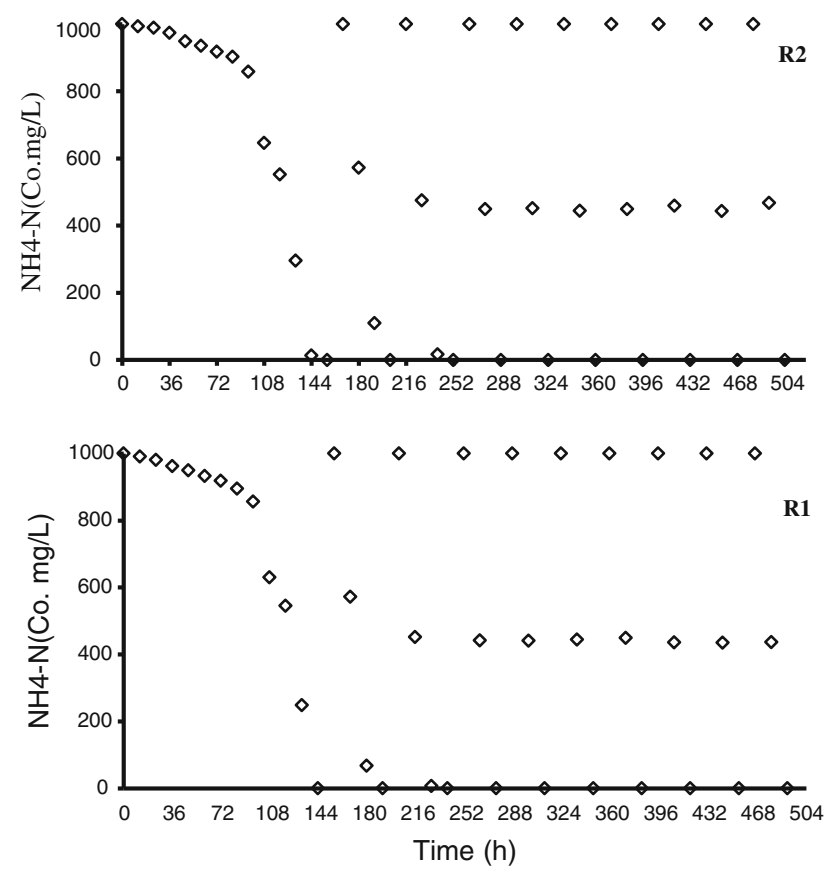

Fig. 2 Ammonium removal profile during growth and adaptation of nitrifying bacteria $(R 1=$ without $\mathrm{COD}$ and $R 2=$ with $\mathrm{COD})$

bacteria. Nevertheless, in this situation, the specific activity of $\mathrm{AOB}$ is lesser than when only nitrifying bacteria are present (Germain et al. 2007; Wu et al. 2008).

Partial nitrification

Substrate concentration is an important parameter in the nitrification process, which can control the rate of ammonium/nitrite oxidation because of its inhibitory effects (Gerardi 2002). The prevailing strategies for incomplete nitrification and depressing the activity of NOB have been mentioned previously. Among them, the accumulation of free FA and FNA has strong and complicated effects on the inhibition of NOB activity (Qiao et al. 2010). The concentrations of both FA and FNA according to Eqs. 3 and 4 are influenced by operational $\mathrm{pH}$, substrate concentration, and temperature (Chen et al. 2010). The threshold inhibition of FA and FNA reported by Anthonisen et al. (1976) is that $\mathrm{AOB}$ was inhibited from $10 \mathrm{mg} \mathrm{FA} / \mathrm{L}$ to $150 \mathrm{mg} \mathrm{FA} /$ $\mathrm{L}$, while the inhibition of NOB began at a concentration of $0.1-1 \mathrm{mg}$ FA/L. The FAN inhibition of FNA takes place with nitrobacteria at FNA concentrations between 0.22 and $2.8 \mathrm{mg} \mathrm{L}^{-1}$ (Anthonisen et al. 1976; Yang et al. 2010), and researchers reported the inhibition of $\mathrm{AOB}$ at FNA concentrations higher than $0.2 \mathrm{mg} \mathrm{L}^{-1}$ (Mosquera-Corral et al. 2005; Qiao et al. 2010).

The effect of the initial organic carbon concentration as a controlling factor in the nitrification process was investigated, using the effect of FA and FNA concentrations as the main strategy to inhibit NOB activity to achieve high PN. Figure 3 shows the FA and FNA concentrations during the acclimatization of nitrifier bacteria at different ratios of $\mathrm{C} / \mathrm{N}$. In the first cycle, the FA and FNA concentrations decreased with enhancement of ammonium elimination ( $R 1$ and $R 2)$. According to the results, due to a high concentration of FA (about $\left.70 \mathrm{mg} \mathrm{L}^{-1}\right)$ and FNA $\left(0.2 \mathrm{mg} \mathrm{L}^{-1}\right)$, ammonium-oxidizing bacteria were dominant and accumulation of $\mathrm{NO}_{3}{ }^{-}-\mathrm{N}$ was negligible in the first cycle of the process. The result depicted in Fig. 4 shows that $\mathrm{NO}_{2}-\mathrm{N} /\left(\mathrm{NO}_{2}-\mathrm{N}+\mathrm{NO}_{3}-\mathrm{N}\right)$ ratio was greater than ratios that were achieved in previous studies by Chen et al. (2010), Ruiz et al. (2003), and Ciudad et al. (2007). The advantages of the current strategy are less washing out and suitable enrichment of $\mathrm{AOB}$, which is aim to be used in a bio-electrochemical reactor (BER).

\section{Kinetics study}

Nitrification comprises oxidation of ammonium to nitrate via nitrite and possibly $\mathrm{N}_{2} \mathrm{O}$ by autotrophic bacteria, as shown by Eq. 5 (Arie Kremen et al. 2005). Researchers have used different kinds of models to describe the rate of nitrification: zero-order kinetics, first-order kinetics (Arie Kremen et al. 2005), and Monod and Haldane model (Chen et al. 2010). According to the zero-order kinetic equation, the rates of $\mathrm{NH}_{4}{ }^{+}$oxidation and $\mathrm{NO}_{3}{ }^{-}$production (where $\mathrm{NO}_{2}{ }^{-}$serves as the substrate) are depicted as Eqs. 6 and 7. Therefore, the rate of $\mathrm{NO}_{2}{ }^{-}$formation is estimated as in Eq. 8, where $\mathrm{KNH}_{4}{ }^{+}$is the specific ammonium oxidation rate $\left(\mathrm{mg} \mathrm{NH}{ }_{4}^{+}-\mathrm{NL}^{-1} \mathrm{~h}^{-1}\right), \mathrm{KNO}_{3}{ }^{-}$is the specific nitrate rate $\left(\mathrm{mg} \mathrm{NO}{ }_{3}^{-}-\mathrm{NL}^{-1} \mathrm{~h}^{-1}\right)$, and $\mathrm{KNO}_{2}{ }^{-}$is the specific nitrate rate $\left(\mathrm{mg} \mathrm{NO}_{3}{ }^{-}-\mathrm{NL}^{-1} \mathrm{~h}^{-1}\right)$.

The rate of ammonium removal according to Eq. (6) in $\mathrm{K} 1$ was $41.66 \mathrm{mg} \mathrm{NH}_{4}{ }^{+}-\mathrm{NL}^{-1} \mathrm{~h}^{-1}$. However, regarding the rate at the beginning of the process, the first cycle in $\mathrm{K} 2$ was less than that in $\mathrm{K} 1$, and complete removal of ammonium in $\mathrm{K} 2$ was conducted after K1, but the result for both reactors showed comparable ammonium removal rates. This means that the rate of ammonium removal was not affected strongly by the presence of heterotrophic bacteria. This was also confirmed by the results of the production rate of $\mathrm{NO}_{2}{ }^{-}$and $\mathrm{NO}_{3}{ }^{-}$(Fig. 4). The gradual oxidation of ammonium resulted in an increase in the nitrate and nitrite concentration, wherein the highest accumulation of nitrite concentration, $936 \mathrm{mg} \mathrm{L}^{-1}$, was observed at the fourth cycle of experiments. The ratio of $\mathrm{NO}_{2}{ }^{-} /\left(\mathrm{NO}_{3}{ }^{-}+\mathrm{NO}_{2}{ }^{-}\right)$was most of the time more than 0.9 for both reactors. Figure 4 confirms the results during $24 \mathrm{~h}$ monitoring of the PN system. 
Fig. 3 The a FA and b FNA concentration in $R 1$ (without $\mathrm{COD}$ ) and $R 2$ (with COD) (first stage; acclimatization of nitrifying bacteria)
Fig. 4 Concentration profiles of ammonium nitrogen, nitrate nitrogen and nitrite nitrogen during $\mathrm{PN}$ and reaction rates described
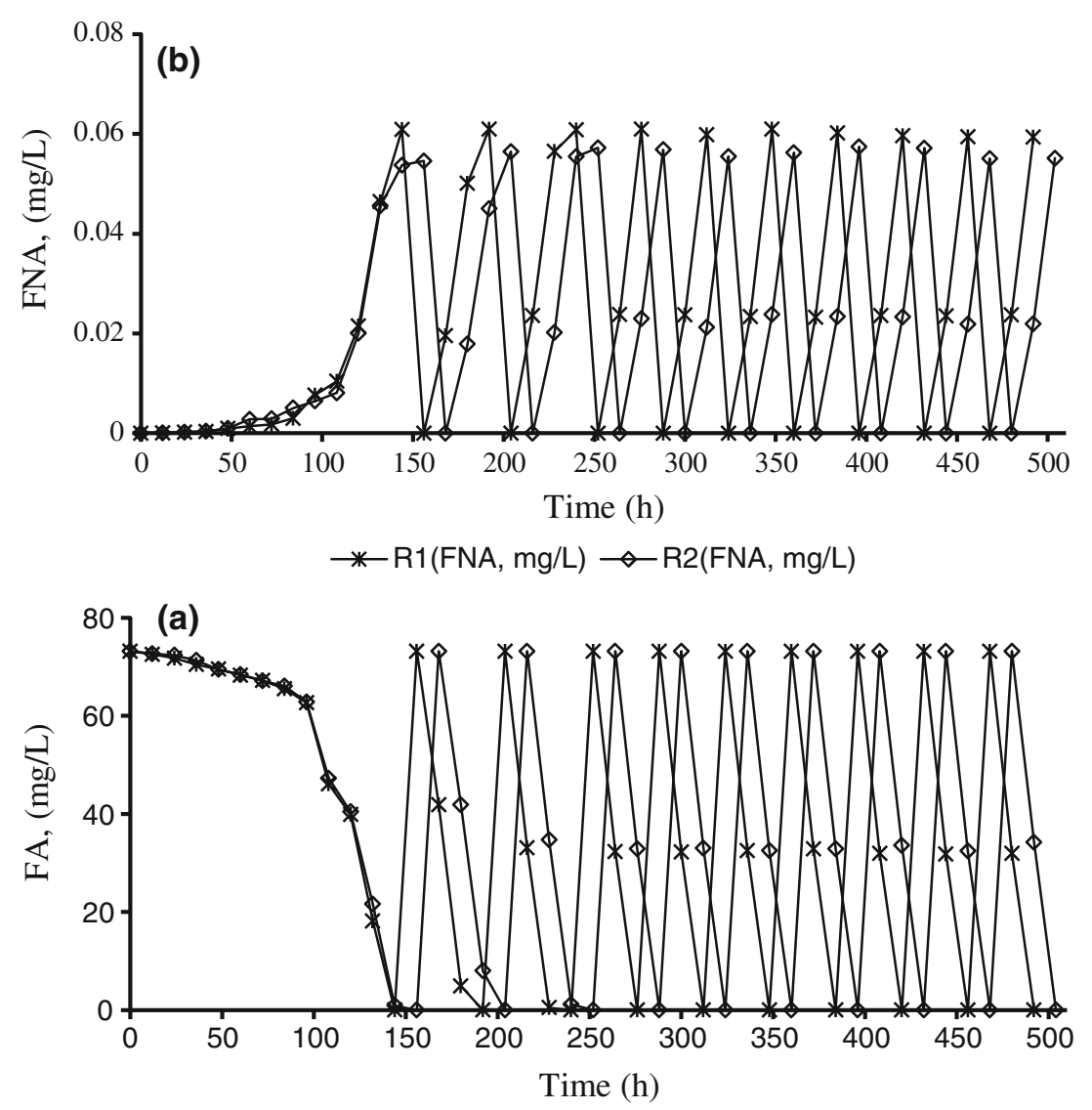

$\rightarrow-\mathrm{R} 1(\mathrm{FA}, \mathrm{mg} / \mathrm{L}) \multimap \mathrm{R} 2(\mathrm{FA}, \mathrm{mg} / \mathrm{L})$

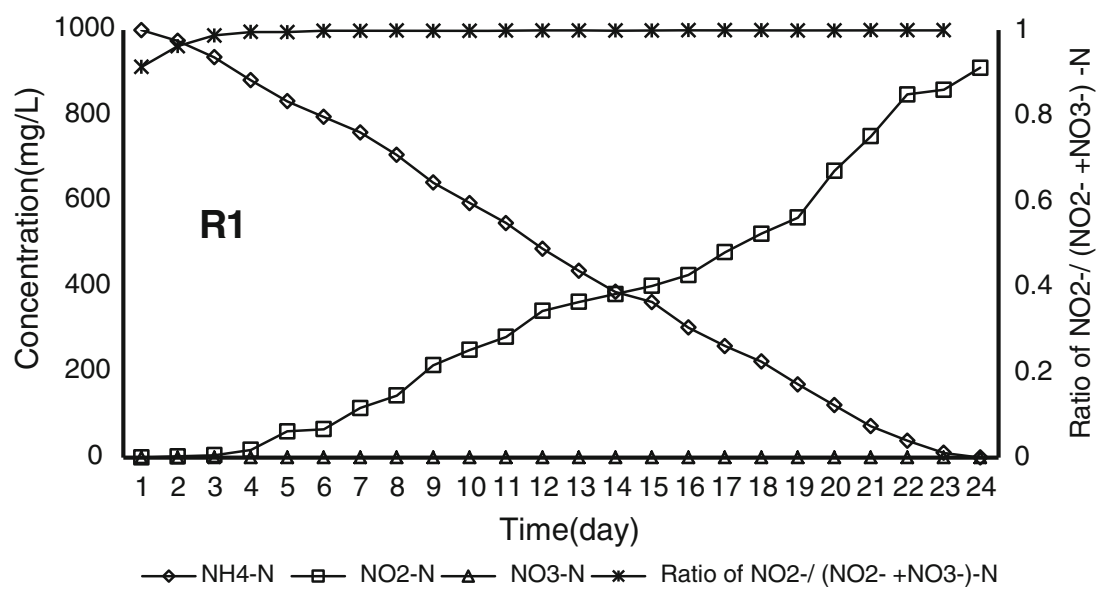

$\frac{\mathrm{d} C_{\mathrm{NO}_{3}^{-}}}{\mathrm{d} t}=-K_{\mathrm{NO}_{3}^{-}} \ldots($ when nitrite is absent $)$

Sludge characteristics

The sludge volume index (SVI) was used to monitor the settling characteristics of activated sludge in both reactors. The initial SVI of sludge was $123 \mathrm{mg} \mathrm{L}^{-1}$, which decreased to $97 \mathrm{mg} \mathrm{L}^{-1}$ after nine cycles of nitrification 

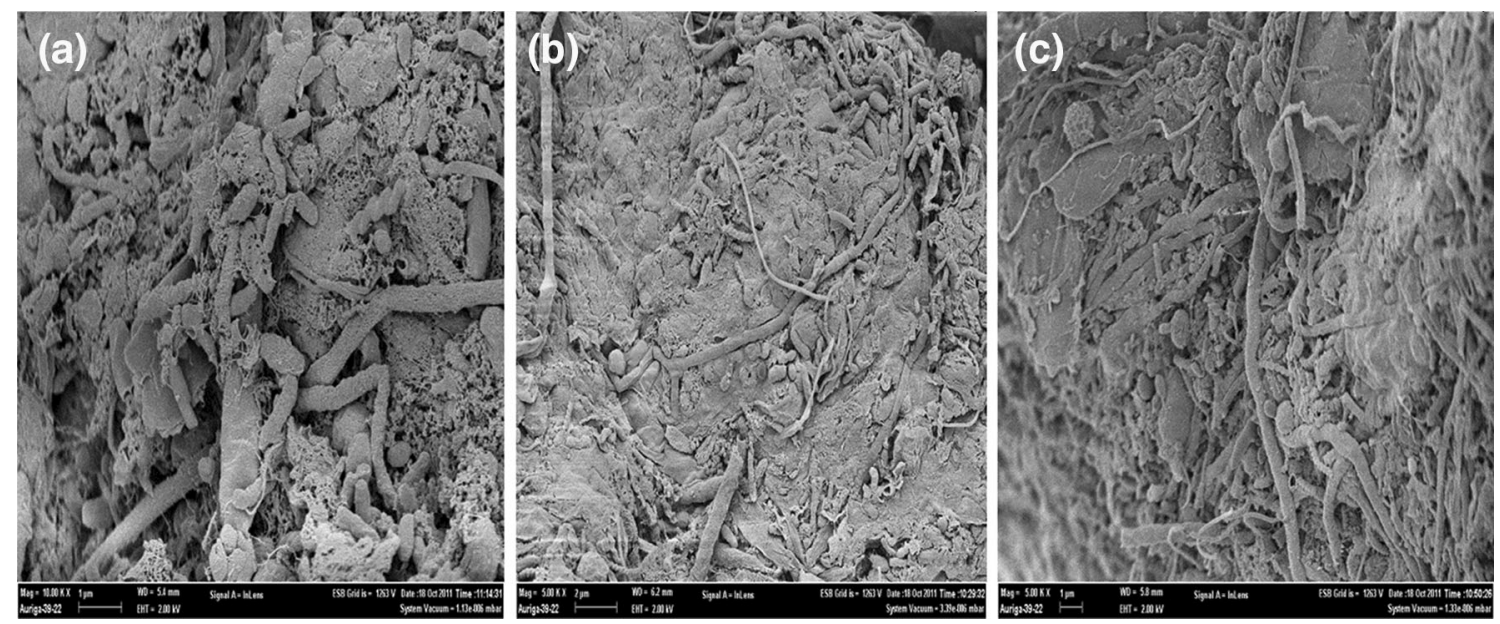

Fig. 5 FESEM images of activated sludge in SBR. a Bacteria at raw sludge; $\mathbf{b}$ bacteria in reactor 1 on day 21 , $\mathbf{c}$ seeded bacteria in reactor 2 on day 21

Fig. 6 Oxygen uptake rate (OUR) by nitrifying bacteria and heterotrophic bacteria in $R 1$ and $R 2$ (during the beginning (I), middle (II), and end (III) of the cycle)

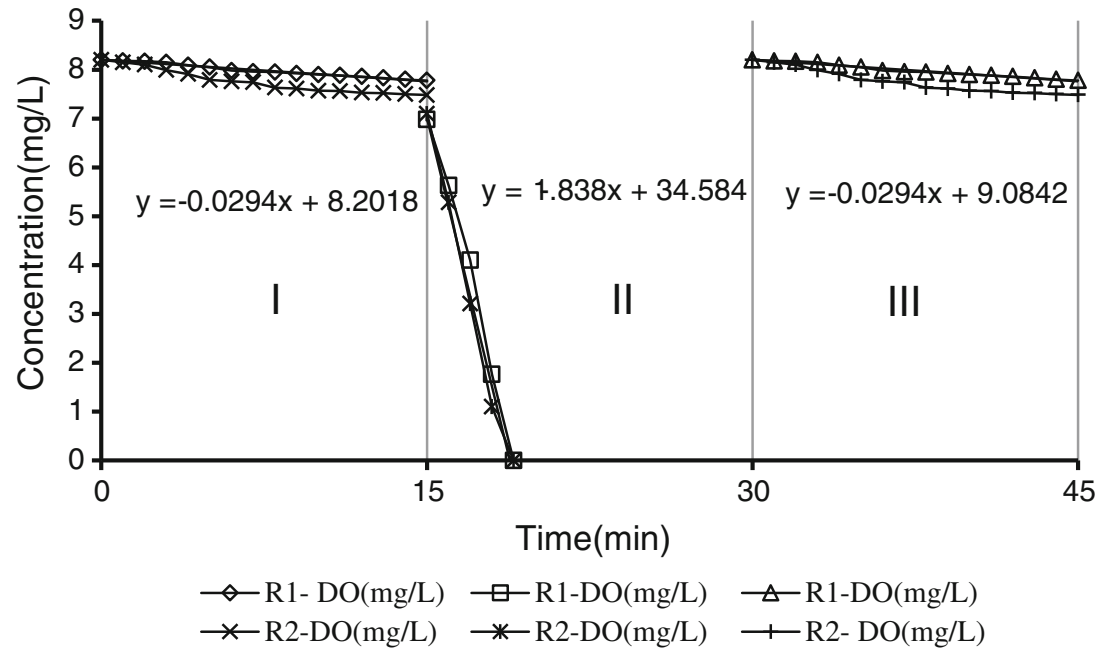

process operation. The results of the measured SVI during the process showed an increase of biomass density, which caused the improvement of sludge-settling properties. During the first cycle, high SVI resulted in the unsuitability of biomass settling. Therefore, the decanted portion of this cycle contained high MLSS. Nevertheless, during subsequent cycles, the settling ability of biomass gradually improved because of high assimilation of substrate by a mixed culture of bacteria in both reactors.

Field emission scanning electron microscopy (FESEM) of the microorganism in SBRs was conducted to observe the morphology of the seed sludge (day 0 and day 21) from the reactor with and without COD. The image of the seed sludge according to Fig. 5a on day 0 shows that the biomass from the urban wastewater treatment plant consists of straight rod, curved rod, and vibroid-shaped bacterial cells, with different sizes of about $0.38-0.6 \mu \mathrm{m}$ and $0.5-1.26 \mu \mathrm{m}$. FESEM observation of sludge revealed an abundance of nitrifying bacteria, which are considered as
AOBs and NOBs in biomass (Fig. 5b) (Gerardi 2002; Qiao et al. 2010; Yusof et al. 2010).

\section{Oxygen consumption rate}

The oxygen uptake rate (OUR) test is a simple, readily available, and familiar way to monitor the nitrification process. The test was applied in all cycles for both reactors. Therefore, the short time span oxygen utilization rate (OUR) test was used to evaluate the nitrification activity in both reactors. At the beginning of the process, the first cycle of OUR was low and the concentration of DO was very high, but with an increase of bacterial activity. The test was conducted for the last cycle of the partial nitrification process at the beginning, middle, and at the end of process. The dissolved oxygen uptake rate was determined by linear regression from the slope of the oxygen utilization curve as shown in Fig. 6. The results show more oxygen uptake rate in reactor R2

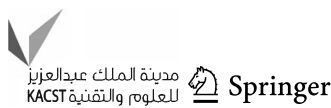


(2.86 $\mathrm{mgO}_{2} \mathrm{~g} \mathrm{VSS}^{-1} \mathrm{~min}^{-1}$ ) because of the presence of heterotrophic bacteria.

\section{Conclusion}

The results of applying various $\mathrm{C} / \mathrm{N}$ ratios showed that a $\mathrm{C} / \mathrm{N}$ ratio of 0 is the most suitable for resulting in faster ammonium removal, in contrast to the use of a $\mathrm{C} / \mathrm{N}$ ratio of 0.5 , in which the nitrification process was slightly inhibited and complete removal of ammonium was carried out for a longer time. Factors FA and FNA are the main strategies of NOB inhibition, where the most significant inhibition was conducted by FA over NOB in both reactors. The rate of ammonium removal was $41.66 \mathrm{mg} \mathrm{NH}_{4}{ }^{-}-\mathrm{NL}^{-1} \mathrm{~h}^{-1}$, and the acclimatization of biomass was conducted at a high ratio of $\mathrm{NO}_{2}{ }^{-}-\mathrm{N} /$ $\left(\mathrm{NO}_{2}{ }^{-}-\mathrm{N}+\mathrm{NO}_{3}{ }^{-}-\mathrm{N}\right)$. The results confirmed that enriched biomass could be inoculums in a PN system to produce high concentration of $\mathrm{NO}_{2}{ }^{-}$with improvement of biomass physical characteristics during an acclimatization process.

Acknowledgments The authors are thankful for the financial support from Universiti Malaya (UM) through Grant No. RG 077/09SUS and the Department of Civil Engineering, UM, for the use of facilities.

Open Access This article is distributed under the terms of the Creative Commons Attribution License which permits any use, distribution, and reproduction in any medium, provided the original author(s) and the source are credited.

\section{References}

Anthonisen AC, Loehr RC, Prakasam TBS, Srinath EG (1976) Inhibition of nitrification by ammonia and nitrous acid. I J Water Pollut Control 48:835-852

APHA et al. (2012) Standard methods for the examination of water and wastewater. American Public Health Association

Arie Kremen JB, Shavit URI, Shaviv AVI (2005) Model demonstrating the potential for coupled nitrification denitrification in soil aggregates. Environ Sci Technol 39:4180-4188

Blackburne R, Yuan Z, Keller J (2008) Demonstration of nitrogen removal via nitrite in a sequencing batch reactor treating domestic wastewater. Water Res 42:2166-2176

Campos JL, Garrido-Fermindez JM, a R L. Méndez JM (1999) Nitrification at high ammonia loading rates in an activated sludge unit. Bioresour Technol 68:141-148

Carrera J, Vicent T, Lafuente J (2004) Effect of influent COD/N ratio on biological nitrogen removal (BNR) from high-strength ammonium industrial wastewater. Process Biochem 39:2035-2041

Chen S, Ling J, Blancheton JP (2006) Nitrification kinetics of biofilm as affected by water quality factors. Aquacult Eng 34:179-197

Chen J, Zheng P, Yu Y, Mahmood Q, Tang C (2010) Enrichment of high activity nitrifers to enhance partial nitrification process. Bioresour Technol 101:7293-7298

Ciudad G, González R, Bornhardt C, Antileo C (2007) Modes of operation and $\mathrm{pH}$ control as enhancement factors for partial nitrification with oxygen transport limitation. Water Res 41:4621-4629

Dosta J, Galí A, Benabdallah El-Hadj T, Macé S, Mata-Álvarez J (2007) Operation and model description of a sequencing batch reactor treating reject water for biological nitrogen removal via nitrite. Bioresour Technol 98:2065-2075

Gerardi MH (2002) Nitrification in the activated sludge process. Wiley Online Library, New York

Germain E, Bancroft L, Dawson A, Hinrichs C, Fricker L, Pearce P (2007) Evaluation of hybrid processes for nitrification by comparing MBBR/AS and IFAS configurations. Water Sci Technol J Internatl Association Water Pollut Res 55:43

Grunditz C, Dalhammar G (2001) Development of nitrification inhibition assays using pure cultures of nitrosomonas and nitrobacter. Water Res 35:433-440

Jianlong W, Ning Y (2004) Partial nitrification under limited dissolved oxygen conditions. Process Biochem 39:1223-1229

Kim J-H, Guo X, Behera SK, Park H-S (2009) A unified model of ammonium oxidation rate at various initial ammonium strength and active ammonium oxidizer concentrations. Bioresour Technol 100:2118-2123

Komorowska-Kaufman M, Majcherek H, Klaczynski E (2006) Factors affecting the biological nitrogen removal from wastewater. Process Biochem 41:1015-1021

Mata-Alvarez SMaJ (2002) Utilization of SBR technology for wastewater treatment: an overview. Ind Eng Chem Res 41:5539-5553

Mosquera-Corral A, Gonzalez F, Campos J, Mendez R (2005) Partial nitrification in a SHARON reactor in the presence of salts and organic carbon compounds. Process Biochem 40:3109-3118

Mousavi S, Ibrahim S, Aroua MK (2012) Sequential nitrification and denitrification in a novel palm shell granular activated carbon twin-chamber upflow bio-electrochemical reactor for treating ammonium-rich wastewater. Bioresour Technol 125:256-266

Okabe S, Oozawa Y, Hirata K, Watanabe Y (1996) Relationship between population dynamics of nitrifiers in biofilms and reactor performance at various C:N ratios. Water Res 30:1563-1572

Qiao S, Matsumoto N, Shinohara T, Nishiyama T, Fujii T, Bhatti Z, Furukawa K (2010) High-rate partial nitrification performance of high ammonium containing wastewater under low temperatures. Bioresour Technol 101:111-117

Rostron WM, Stuckey DC, Young AA (2001) Nitrification of high strength ammonia wastewaters: comparative study of immobilisation media. Water Res 35:1169-1178

Ruiz G, Jeison D, Chamy R (2003) Nitrification with high nitrite accumulation for the treatment of wastewater with high ammonia concentration. Water Res 37:1371-1377

Van Benthum W, Van Loosdrecht M, Heijnen J (1997) Control of heterotrophic layer formation on nitrifying biofilms in a biofilm airlift suspension reactor. Biotechnol Bioeng 53:397-405

Van Kempen R, Mulder J, Uijterlinde C, Loosdrecht M (2001) Overview: full scale experience of the SHARON ${ }^{\circledR}$ process for treatment of rejection water of digested sludge dewatering. Water Sci Technol 44:145-152

Volcke EIP, Gernaey KV, Vrecko D, Jeppsson U, van Loosdrecht MCM, Vanrolleghem PA, Kroiss H (2006) Plant-wide (BSM 2) evaluation of reject water treatment with a SHARON-Anammox process. Citeseer

Whang L-M, Chien IC, Yuan S-L, Wu Y-J (2009) Nitrifying community structures and nitrification performance of full-scale municipal and swine wastewater treatment plants. Chemosphere $75: 234-242$

Wu G, Rodgers M, Zhan X (2008) Nitrification in sequencing batch reactors with and without glucose addition at $11{ }^{\circ} \mathrm{C}$. Biochem Eng J 40:373-378 
Yang J, Zhang L, Daisuke H, Takahiro S, Ma Y, Li Z, Furukawa K (2010) High rate partial nitrification treatment of reject wastewater. J Biosci Bioeng 110:436-440

Yusof N, Hassan MA, Phang LY, Tabatabaei M, Othman MR, Mori M, Wakisaka M, Sakai K, Shirai Y (2010) Nitrification of ammonium-rich sanitary landfill leachate. Waste Manag 30:100-109

Zheng P, Xu XY, Hu BL (2004) Novel theories and technologies for biological nitrogen removal. Science Press, Beijing 